\title{
Overview of Congenital, Senile and Metabolic Cataract
}

Keywords: Cataractous lens, Congenital, Senile cataracts, Genetic factors, Metabolic pathways

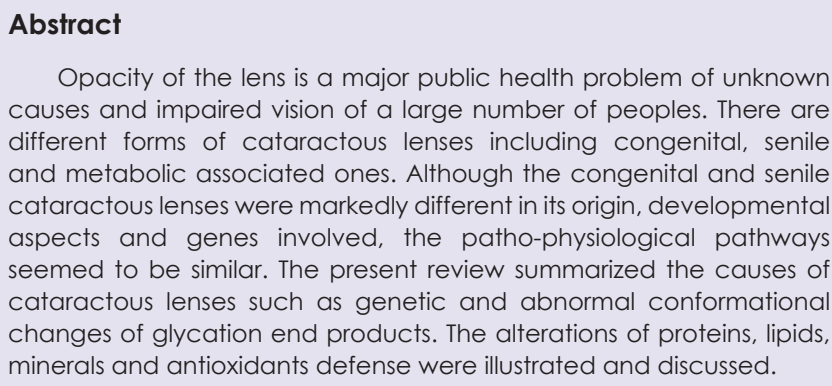

Opacity of the lens is a major public health problem of unknown causes and impaired vision of a large number of peoples. There are different forms of cataractous lenses including congenital, senile and metabolic associated ones. Although the congenital and senile cataractous lenses were markedly different in its origin, developmenta aspects and genes involved, the patho-physiological pathways seemed to be similar. The present review summarized the causes of cataractous lenses such as genetic and abnormal conformationa changes of glycation end products. The alterations of proteins, lipids, minerals and antioxidants defense were illustrated and discussed.

\section{Introduction}

The lens is avascular biconvex ellipsoid transparent tissue, present in front of the anterior chamber of the eye; just behind the cornea. It is an ectodermal organ, developed at the $25^{\text {th }}$ day of gestation. By the second month of intra-uterine growth, the spherical criteria structure of the lens is developed with characteristic anterior and posterior pole and dorsally outlined by lens epithelium. The lens fibers developed and matured after birth with subsequent formation of crystalline protein especially in adult state [1].

The cornea is affected by continues light exposure which may be reflected in the structure of the lens with age. The lens comprises three main regions; capsule, lens epithelium, and lens fibers. The capsule is made up of dense connective tissue. The lens epithelium; lined the surface and it comprises a simple cuboidal epithelium. It possesses a vital function by regulating the homeostatic functions allowing the permeability of ions, nutrients, and osmolarity to the aqueous humor. It develops earlier during utero life in the 5th-6th week of gestation and maintains its normal integrity throughout [2]. The entire body of the lens is composed of concentric layers of tightly backed lens fibers interdigitated with each other by a ball and socket. Glucose represents the primary energy source of the lens tissues [3]. Sodium/potassium adenosine triphosphatase and calcium adenosine triphosphatase promote the osmolarity of the lens fibers [4].

Damage of the lens fibres lead to the formation of clouding in the lens and scattering of light, the predictor of cataract. It increases with age with a prevalence of about $50 \%$ in over 80 years old individuals [5]. There are different forms of cataracts; namely congenital [6] agerelated cataract [7] and metabolic cataract [8].

\section{Congenital \& Senile Cataract}

Cataract is a clouding of the eye's natural lens which causes visual impairment. More than 17 million people are blind due to cataract and 2800 new cases are known throughout the world daily [5].

Congenital cataract are developed during intra-uterine growth as a result of environmental and genetic factors and observed after parturition. Approximately half of all congenital cataracts are

\section{Journal of}

Ocular Biology

Hassan I.H.El-Sayyad ${ }^{1 *}$, Eman HM Bakr', Heba A. El-Ghawet ${ }^{1}$ and Taher M G E El-Desoky ${ }^{2}$

${ }^{\text {I}}$ Faculty of Science, Mansoura University, Mansoura, Egypt

${ }^{2}$ Ophthalmic Surgery, Ophthalmic Center, Mansoura University, Egypt

*Address for Correspondence

Hassan I El-Sayyad, PhD, Faculty of Science, Mansoura University, Mansoura, Egypt, Tel: 0020502254850; E-mail: elsayyad@mans.edu.eg

Submission: 26 September 2015

Accepted: 13 October 2015

Published: 02 November 2015

Copyright: $\odot 2015 \mathrm{El}-\mathrm{Sayyad} \mathrm{HIH}$, et al. This is an open access article distributed under the Creative Commons Attribution License, which permits unrestricted use, distribution, and reproduction in any medium, provided the original work is properly cited.

Reviewed \& Approved by: Dr. Li Wang, Associate Professor of Ophthalmology, Cullen Eye Institute, Department of Ophthalmology, Baylor College of Medicine, USA

idiopathic [9] and particularly, a cause for unilateral cataract is rarely found [10].

Congenital cataracts are of different genetic type, and more than 25 loci and genes on different chromosomes are involved in the disease [11]. Rahi and Dezateux reported a similar genotype in $27 \%$ of children with bilateral congenital cataract [12].

In age related cataract, many changes have been found to have occurred in the lens structure which facilitated the opacities of lens fibres. The epithelia of nuclear, posterior subcapsular, mature, mixed, hypermature, and black cataracts of male and female patients revealed that the $56 \%$ superimposed epithelial cells are probably the source of increased and altered cell activity. Senile cataract is classified into; mature or immature, nuclear cortical and posterior subcapsular cataract [13]. Investigation of 233 cataractous patients, revealed apparent increased incidence of nuclear, cortical, and posterior subcapsular cataract in older patients. These were correlated with lower expression of SIRT1 in patients [14].

\section{Mechanism of Cataract Formation}

Metabolic diseases were found to be associated with the activation of the sorbitol pathway [15] that enhanced the progress of cataract formation. Liberation of free radicals is more common as a result of these diseases. In vivo and in vitro studies revealed that hydrogen peroxide $\left(\mathrm{H}_{2} \mathrm{O}_{2}\right)$ is related to the accumulation of $\mathrm{A} \beta$ in the lenses of rats and causes lens opacification [16]. The incidence of cataractous lenses was markedly increased among patients with metabolic diseases such as hypertension [15] and diabetes [17]. Hypertensive patients showed significantly higher nitrite levels in their cataractous lenses were detected in $26(44.1 \%)$ especially that of posterior subcapsular cataracts $[18,19]$.

Moncaster et al. reported increased amyloid accumulation and supranuclear cataracts in the ocular lenses of patients with Alzheimer's disease [20].

There are different pathways for the formation of cataract (Figure 1), they include: 


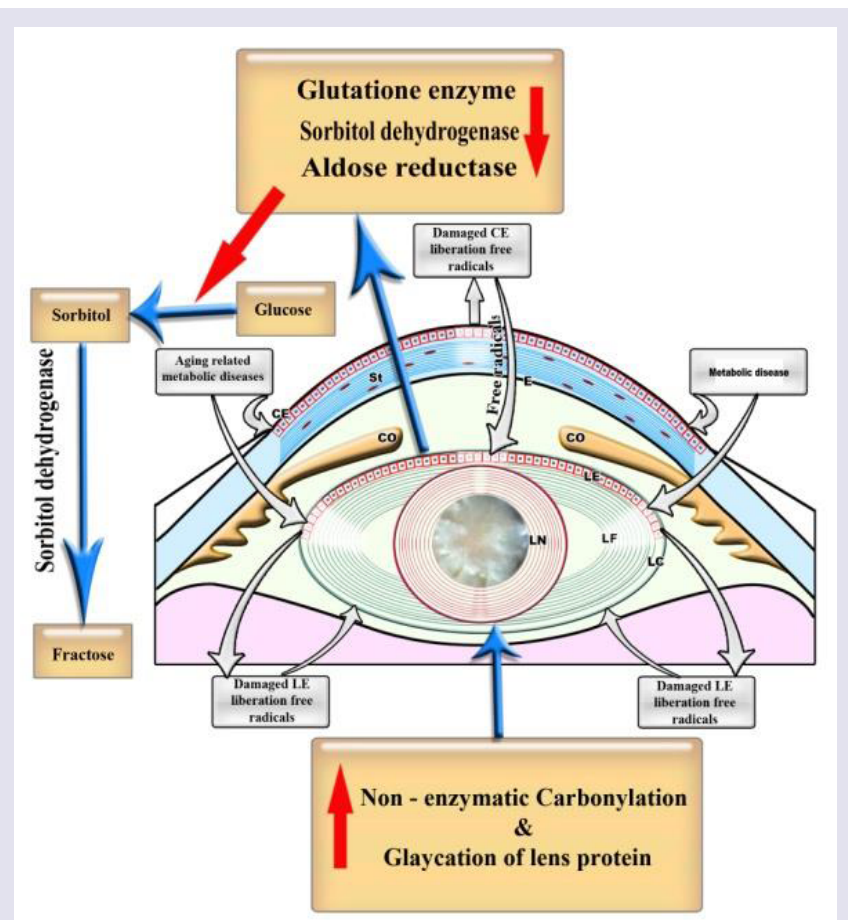

Figure 1: Chart illustrates the mechanism of cataract formation Abbreviations: CE: Corneal Epithelium; CO: Ciliary Organ; E: Endothelium; LC: Lens Capsule; LE: Lens Epithelium; LF: Lens Fiber; LN: Lens Nucleus; St: Stroma.

\section{Polyol pathway}

In diabetic cataractous lens, there was a marked increase of damaging lens epithelium [21] associated with over production of free radicals and decreased capacity of antioxidant defense system. These were associated with a depletion of the activities of aldose reductase and sorbitol dehydrogenase while G6PD and glutathione system enzyme activities were found to be lower in cataractous lenses from diabetes [22]. Aldose Reductase is a key enzyme involved the reduction of glucose into sugar alcohol sorbitol, which is metabolized to fructose by sorbitol dehydrogenase. Sorbitol was found to accumulate in lens cells causing osmolysis, leakage of glutathione, myo-inositol, the generation of free radicals which contributed to diabetic complication such as cataract $[23,24]$. The enzyme is more active in diabetes and implicated in cataractous lenses $[25,26]$.

Sugar cataract formation was found to have resulted from lenticular sorbitol accumulation. In the lens, increase of aldose reductase is contradicted with a decrease of the activity of sorbitol dehydrogenase [27]; it increases the accumulation of sorbitol rapidly than it is converted to fructose [28] which induces apoptosis of lenticular epithelial cells and subsequent cataracts [29]. Diabetes was found to express poly(ADP-ribose) polymerase(PARP) in lens [30] which in turn led to $\mathrm{NAD}^{+}$depletion and energy failure and also contributed to necrosis and apoptosis [31].

Intracellular accumulation of sorbitol is associated with marked increase of oxidative stress in the endoplasmic reticulum (ER), the principal site of protein synthesis, it initiates the liberation of free radicals and also involved in the breakdown of lens fibers $[32,33]$.
Over-expression of aldose reductase also enhanced the expression of both extracellular signal-regulated kinase (ERK1/2) and c-Jun $\mathrm{N}$-terminal (JNK1/2), which are involved in apoptosis [34].

In sugar cataracts, the initial swelling brought about by polyol accumulation leads to an imbalance in the pump-leak equilibrium, increasing sodium and chlorine content. Genetic mouse cataract was found to exhibit the imbalance of the pump-leak system which appeared to be initiated by a deficiency of $\mathrm{Na}-\mathrm{K}$ ATPase which facilitates sodium retention and osmotic swelling [35].

Nagai et al. reported a decrease in the activity of $\mathrm{Ca}^{2+}$-ATPase in the lenses of Shumiya cataract rat (SCR) and Ihara cataract rat (ICR), which is concurrent with the development of cataract [36]. The expression of cytochrome $\mathrm{c}$ oxidase (CCO)-1 mRNA and CCO activity in UPLR lenses was found to have decreased during cataract development. Both nitric oxide (NO) and lipid peroxide were markedly increased in the lenses of UPLR, SCR and ICR with opaque lenses. Increased liberation of NO may enhance lipid peroxidation resulting in the inhibition of $\mathrm{Ca}\left({ }^{2+}\right)$-ATPase and elevation in lens $\mathrm{Ca}\left({ }^{2+}\right)$, leading to lens opacification in ICR/f rats.

Glycation end product (AGE): AGE is a non-enzymatic glycation of lens proteins by reducing sugars (glucose, galactose etc) resulting in the formation of protein aggregates that precipitate in the lens $[37,38]$ and represent a causative factor of damaging lens epithelial cells (LECs), the promoter of cataract formation [39]. The receptor for advanced glycation end-products (RAGE) and proliferating cell nuclear agents (PCNA) are over-expressed in old-age and diabetes which is involved in cataract formation [40,41]. Advanced glycation end products (AGEs) including carboxymethyl lysine (CML) was found to be increased in diabetic and senile cataractous lenses [42].

The urea-insoluble fraction, showed the highest levels of AGEs [43]. Pentosidine, CML, and imidazolone were markedly increased in cataractous lenses [44]. In vitro and in vivo studies revealed AGE induced apparent apoptosis of LECs through enhancement of accumulation of argpyrimidine and nuclear factor- kappaB (NF- $\kappa B)$. The ratio of Bax to Bcl-2 protein levels was also increased [39].

Cataractous lenses were markedly higher in women especially those with diabetes [45]. In cataractous lens of 21-week-old male ZDF rats, increased apoptosis of LECs was correlated with upregulated expression of iNOS mRNA and protein, causing the accumulation of glycated proteins in their cytoplasm, meanwhile activated NFkappaB was mainly detected within their nuclei [46].

\section{Genetic Role of Cataract Formation}

There are multifactorial agents that contribute in the development of cataractous lenses as well as between congenital and age-related cataracts. Congenital cataract affects childhood, and different intrauterine factors are involved (Figure 2). The genetic incidence accounts for 8.3 and $25 \%$ cataract. Congenital cataracts may result from chromosomal abnormalities such as neurofibromatosis type 2 or homeobox gene PITX3 [47,48] classified congenital abnormalities into mature, polar (anterior or posterior), zonular (nuclear, or lamellar), and capsular or membranous.

Zhu et al. attributed the congenital cataract to the mutation 


\section{Incidence 3.18 per 10,000, Connexin 50, Syntaxin 3, Chromosome 16 (D16Mit5 \&D16Mit9/ D16Mit92 \& D16Mit201)}

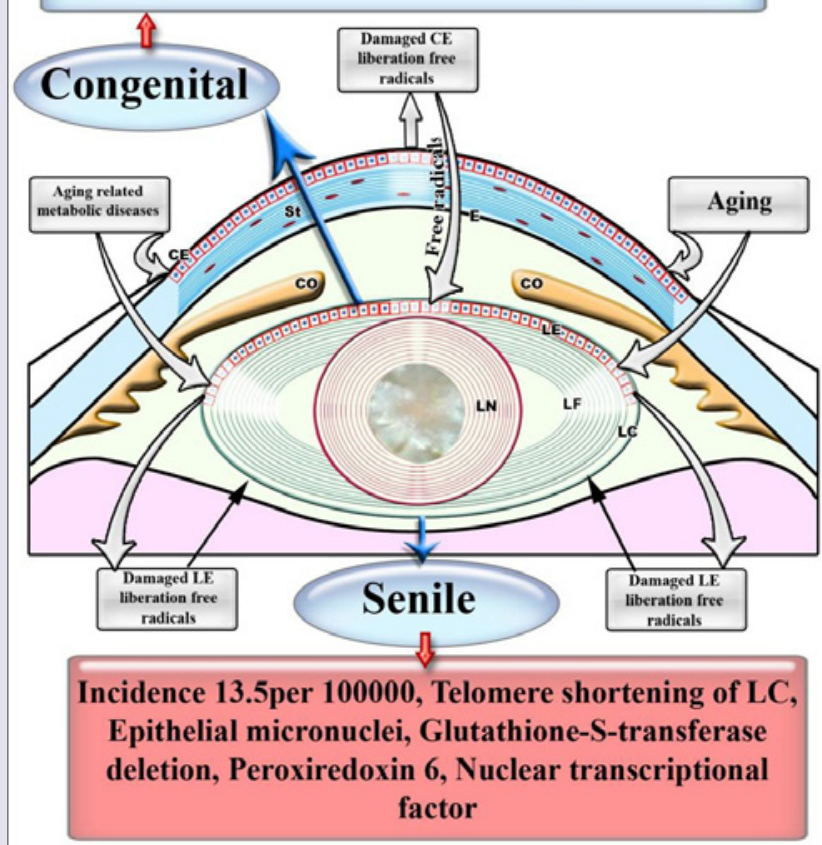

Figure 2: Diagrammatic representation the incidence and genetic role in congenital and senile cataract formation.

Abbreviations: CE: Corneal Epithelium; CO: Ciliary Organ; E: Endothelium; LC: Lens Capsule; LE: Lens Epithelium; LF: Lens Fiber; LN: Lens Nucleus; St: Stroma.

of connexin 50 of a valine residue with alanine at codon 44 [49] In cataract lenses of KO-Dp71 mice and wild-type (wt), Fort et al. reported increased incidence of cataracts with subsequent lack of Dp71 (dystrophin gene of Duchenne muscular dystrophy) [50].

Khan et al. observed posterior cortical lenticular opacities with over-expression of a novel missense mutation in KCNJ13 in 12-yearold Saudi Arabian girl with nystagmus [51].

$\mathrm{CF} 1 / \mathrm{b}$ mouse strain (an outbred colony) reared at Osaka Prefecture University was found to develop cataracts at $14 \mathrm{~d}$ old in the form of vacuolated lens epithelial cells, swollen lens fibers, pyknotic nuclei, and vacuolation of the lens cortex. Cataractous lens was found to result from autosomal recessive mutation genes in mouse chromosome 16 between D16Mit5 and D16Mit92 and between D16Mit92 and D16Mit201 [52].

Lens syntaxin 3 gene interfered with lens protein structure and function. Mutation of this gene results in the development of autosomal recessive congenital cataract [53]. Inherited forms of cataract are characterized by mutation in the gene of cation channel and member-3 (TRPM3, melastatin-2). Genome-wide linkage analysis mapped the ocular disease locus to the pericentric region of human chromosome 9 [54].

Although congenital cataracts may alter vision; sparse individuals are affected, age-related cataracts are responsible for blinding 17 million people worldwide [55].

In age related cataract, many changes had been found to have occurred in the structure of the lens which facilitated the opacities of lens fibres. Telomerase represents one of the genetic factors. It is a naturally occurring enzyme that maintains telomeres and prevents them from shortening during cell division. Telomerase consists of at least two components: an RNA template (hTR), which binds to the telomere and a catalytic subunit (hTERT) with reverse transcriptase activity, which adds a specific DNA sequence to the chromosome ends. During the formation of cataract, telomeres attained a considerable atrophy in lens epithelial cells due to increased oxidative stress of the lens cell membranes and biomolecules [56,57]. Cataractous patients possessed the presence of a large number of micronuclei (MN) in their epithelia, manifesting epithelial damage [58].

MicroRNA-125b (miR-125b) is responsible for lens epithelial cell apoptosis. In vitro studies of miR-125b revealed increased incidence of human lens epithelial cell apoptosis through assessments of p53. In age-related cataract, there was an inverse relationship between miR$125 \mathrm{~b}$ and p53 expression [59]. Oxidative stress and DNA damage contributed to the pathogenesis of age-related cataract (ARC) [60].

Oxidative stress represents the main factor responsible for lenticular cataract. Glutathione-S-transferase (GST) catalyses the nucleophilic addition of the thiol of GSH to electrophilic acceptors, it is important for protecting tissues from oxidative damage. In humans, GSTT1 and GSTM1 deletion genotypes are associated with a variety of ophthalmic diseases. The frequency of GSTM1 affected individuals was markedly increased in MT cataracts followed by NC, CC and PSC types [61].

Peroxiredoxin $6(\operatorname{Prdx} 6)$ is a new family of antioxidants which regulates gene expression and function by scavenging reactive oxygen species and protects lens epithelial cells of rat. Oxidative stress was found to have contributed in the formation of nuclear or cortical cataract through a decrease of Prdx6 in cataractous lenses especially during aging [62].

Nuclear transcriptional factor, NF-E2-related factor 2 (Nrf2), plays an integral role against oxidative stresses by promoting 20 different antioxidative enzymes. Kelch-like ECH associated protein 1 (Keap1) targets and binds to Nrf2 for proteosomal degradation. Palsamy et al. detected significant levels of demethylated DNA in the Keap1 promoter in the diabetic cataractous lenses [63]. Human lens epithelial cell lines (HLECs) treated with a demethylation agent, 5-aza-2'deoxycytidine (5-Aza), showed 10-fold higher levels of Keap1 mRNA, 3-fold increased levels of Keap1 protein, which enhanced the liberation of free radicals and increased cell death. Decreased Nrf2 activity depleted the transcription of many antioxidant enzyme genes and altered the redox-balance towards lens oxidation. During agingrelated cataract, there was a considerable reduction of protein and gene expression level of nuclear transcriptional factor, NF-E2-related factor 2 (Nrf2) in lenses. Over-expressed Keap1 protein is responsible for decreasing Nrf2 by proteasomal degradation, thereby suppressing Nrf2-dependent stress protection. Therefore, decreased activity of Nrf2 restrained the transcription of its downstream antioxidant enzyme and led to the failure of the antioxidant system; ultimately 
leading to the formation of ARCs [64,65].

In experimental animals, different pathways are involved. Transgenic mice were found to express ectopic Col4a3 and Col4a 4 genes in the lens which have the capability of activating IRE1, ATF6, and PERK associated with the expansion of the endoplasmic reticulum and attenuated protein translation. These were associated with damaging lens epithelium and accumulate terminally unfolded proteins [66]. Following the study of three mice lens epithelial cells (LECs) 17EM15, 21EM15 and $\alpha \mathrm{TN} 4$, Terrell et al. reported that the expressed genes Foxe3, Pax6, Anxa4 and Mcm4 were up-regulated in lens epithelial cell lines (LEC), compared to lens fiber cells [67]. All the three LECs exhibited down-regulation of fiber cell-expressed genes Crybb1, Mip and Prox1 as well as over-expressed cataractassociated genes, such as Dkk3, Epha2, Hsf4, Jag1, Mab21l1, Meis1, Pknox1, Pou2f1, Sfrp1, Sparc, Tdrd7 and Trpm3.

\section{Lipid and Cataracts}

Lipids are of functional importance to lens. About 172 lipid species were identified mainly as sphingomyelins, phosphatidylcholines, and phosphatidylethanolamines. Also, 20 phosphatidylcholines, 6 phosphatidylethanolamines, and 4 phosphatidic acids were also detected [68]. The lens transmit light through thousands of cellular membranes rich in phospholipids especially dihydrosphingomyelin. Most of the lipids are associated with proteins. Sphingolipids represent $60 \%$ of human lens and represents the main integral part in its transparency. Lens glycolipids are composed of 4-sphingenine (sphingosine) to which carbohydrates are bound [69] and represents $1 \%$ of the total human lens lipid but are of valuable importance for differentiation of lens epithelial cells to lens fibers [70].

Lipids represent the main structural components of the lens membranes and have profound effect on its fluidity. Cataractous lens involves protein aggregation as a result of losing stability in protein conformation. Age-related changes in lipid composition could be a contributing factor for altered protein-lipid interaction leading to protein aggregation and cataract formation [71]. The lens membranes exhibited three distinct lipids such as the bulk, nuclear, and trapped lipid domain. The cholesterol bilayer was detected in the cortical and nuclear lens lipid membranes, and missing in the intact membranes. The amount of lipids combine proteins was increased in the nuclear than in cortical membranes facilitating rigidity of nuclear membranes and increasing permeability in the cortical ones [72].

Cataractous lenses were found to exhibit membrane derangement, widespread of vacuoles and clusters of highly undulating membranes. Damage of the lens fiber cell membranes impairs vision and interferes with light-scattering which causes lens opacity. Phospholipid molecules modified by oxygen accumulate in the lipid bilayer, they have been found to change their geometry and impair lipid-lipid and protein-lipid interactions in the lenticular fiber membranes [73]. Human cataractous lenses contain the long chain base glycolipids (C18a sphingosine (sphinganine). The major fatty acids were C160, C24:1 and C24:0, and monounsaturated fatty acids accounted for 40$55 \%$ the total fatty acids [74]. Siddique et al. reported alterations of phospholipid and protein moieties in lens fibers, disrupting function and leading to cataract formation (Figure 3) [75].

The content of palmitic acid showed apparent increase in

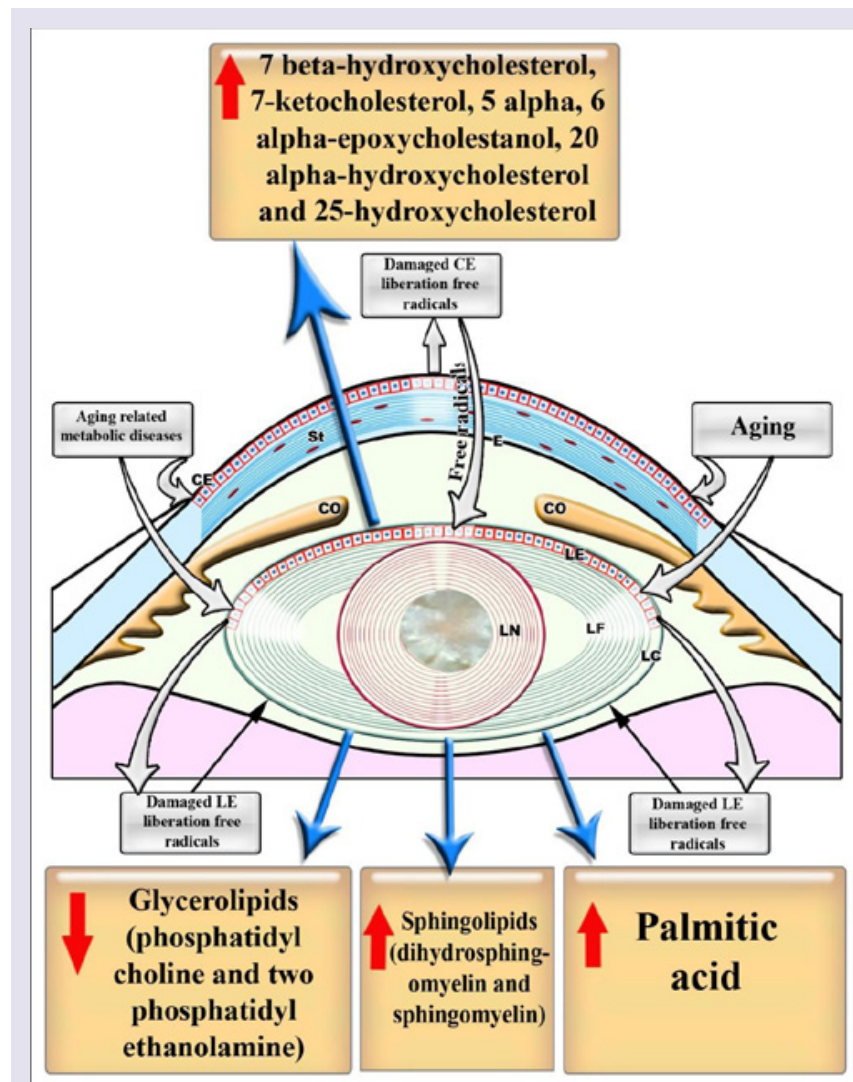

Figure 3: Diagrammatic representation the role of lipids in senile cataract formation.

Abbreviations: CE: Corneal Epithelium; CO: Ciliary Organ; E: Endothelium; LC: Lens Capsule; LE: Lens Epithelium; LF: Lens Fiber; LN: Lens Nucleus; St: Stroma.

cataractous lens when compared with marked depletion of oleic acid, linolenic acid and docosahexaenoic acid [76].

Huang et al. detected increased amount of sphingolipids (dihydrosphingomyelin and sphingomyelin) compared with apparent depletion of glycerolipids (phosphatidylcholine and two phosphatidylethanolamine) in cataractous lens [77].

Lipid peroxidation (LPO) is a pathogenic factor in cataract. It includes diene conjugates, lipid hydroperoxides, oxy-derivatives of phospholipid fatty acids and present in the lipid moieties of aqueous humour and lenses of senile patients [73]. Plasma membranes of the ocular lens are rich in fiber junctions which in turn have $20-40 \%$ of total lipid content compared with that of the total plasma membrane. In the bovine nucleus, the cholesterol/phospholipid molar ratio was markedly increased in the fiber junctional-enriched membrane than in the total plasma membrane, suggesting a special association of cholesterol with bovine nuclear fiber junctions [78]. In cataractous human lenses, the ratio of cholesterol to phospholipid (Chol/PL) attained a considerable increase in lens membranes.

Exposure of membranes isolated from transparent human lenses to the free radical generator were found to produce 7 alphahydroxycholesterol (6\%), 7 beta-hydroxycholesterol (19\%), 5 alpha, 6 alpha-epoxycholestanol (1\%) and 7-ketocholesterol (74\%) as 
Citation: El-Sayyad HIH, Bakr EHM, El-Ghawet HA, El-Desoky TMGE. Overview of Congenital, Senile and Metabolic Cataract . J Ocular Biol. 2015;3(2): 12

major oxidation products. Cataractous lenses possessed moderate amounts of 7 beta-hydroxycholesterol, 7-ketocholesterol, 5 alpha, 6 alpha-epoxycholestanol, 20 alpha-hydroxycholesterol and 25-hydroxycholesterol compared with no-detectable amounts in clear lenses [79]. Studies have shown that cholesterol contributes to the impermeability of oxygen across the lens membranes [80]. Maintaining low levels of oxygen is important to the lens to prevent oxidation and cataract formation. One of the main function of the mitochondria, present in the epithelium and outer cortical fibers [81] is to degrade oxygen [82]. The cholesterol-related impermeability of the membranes to oxygen may help to keep oxygen in the outer regions of the lens long enough for the mitochondria to degrade it.

The etiology of lipids in cataract formation led Deeley et al. to investigate the variation of eye lipid contents in humans and experimental animals [83]. The authors found that the most abundant phospholipids in all the lenses examined were cholinecontaining phospholipids. Human lens showed wide variations of lens lipid components compared with rat, mouse, sheep, cow, pig and chicken. Sixty six percent (66\%) of the total phospholipid in Homo sapiens was sphingomyelin (dihydrosphingomyelins). The abundant glycerophospholipids in human lenses were phosphatidylethanolamines and phosphatidylserines. Experimental and domestic animals showed abundant phosphatidylcholines in their lenses. Several neutral and acidic glycosphingolipids were observed in rat lens epithelia, cortex and nucleus. Immunohistochemical staining revealed apparent concentration of gangliosides GM3 and GM1 in the anterior lens epithelial cells and the cortex, with gradual decrease toward the lens nucleus. GD3 appeared more intense in the lens nucleus than in epithelial cells [84]. Adult rat lens were found to have a complex ganglioside consisting of six major components identified as GM3, GD3, GD1a, GD1b, GT1b, and GQ1b based on their reactivity to anti-GM1. The relative concentration of GT3 in total gangliosides of the eye lens was highest among neural and extra-neural tissues examined. Administration of streptozotocin to rats caused a severe reduction in the GD3 content in the eye lenses within three days prior to other gangliosides alterations [85]. Emory mouse cataracts undergo protein oxidation by the formation of hydrazone with 2, 4-dinitrophenyl hydrazine. The lipid oxidation was observed from a depletion of oleic acid and over-expression of ketoacids [86]. The relative and absolute amount of sphingolipids, including dihydrosphingomyelin and sphingomyelin, increased with age parallel with the development of cataractous lenses. Increased membrane stiffness led to light-scattering, reduced calcium pump activity, altered protein-lipid interactions, and decreased fiber cell elongation [77].

\section{Protein and Cataracts}

The lens protein attained nearly $33 \%$ of its net weight. Crystallins are the main protein components in the lens reaching up to $90 \%$ of total soluble protein. Other proteins form the cytoskeletal and membrane structure such as actin, filensin and spectrin, transporters and channel proteins and junctional proteins. There are three distinct forms of crystallins; $\alpha$-, $\beta$ - and $\gamma$-crystallins. $\alpha$ - and $\beta$-crystallins are present in oligomers, compared with the monomer form of $\gamma$-crystallin [87]. In adults, the nucleus represents the major part of the lens. The nucleus is concerned with cell communication and many enzymes involved in metabolism, protein synthesis and degradation [88].

In old age, there is a marked disruption of lens disulphide protein aggregates and conformation which is unique to cataract. In cataracts, $60 \%$ of the methionine is bounded to the lens membrane. Most of the disulfide amino acids bind with glutathione to form $\alpha$-crystallin via oxidative changes [89]. Homozygous alpha alanine-cysteine mutant mice, possessed apparent characteristic loss of cytological structure of lens epithelial and fiber cells such as actin filaments and mitochondria (alpha, beta, and gamma classes) [90]. Alpha-A crystallin represents the major protein of the lens and is composed of a mixture of cysteine sulfhydryl and half-cysteine disulfide groups. Oxidation of cysteine sulfhydryl groups may be involved in opacification of lens [91].

Crystallins are categorized in three forms $\alpha, \beta$, and $\gamma$. The $\beta$-crystallins remain the most elusive form due to their greater number of subunits and possible oligomer formations and changes during aging. Deamidation of $\beta$-crystallins occurred during aging in cataractous lenses and $\alpha$-crystallin chaperone impaired the cataractous changes [92]. The cysteine is characterized by having disulfide bond with the low molecular weight thiol in the lens. The appearance of gamma-Glu-Cys may be coincident with biochemical abnormalities preceding cataract formation. This protein modification may result from changes in the GSH biosynthetic pathway within the lens $[93,94]$. In cataractous patients with or without diabetes, there were marked aggregations of two types, soluble and insoluble proteins. Higher levels of m-Tyr, o-Tyr, DOPA and Phe/protein ratio were

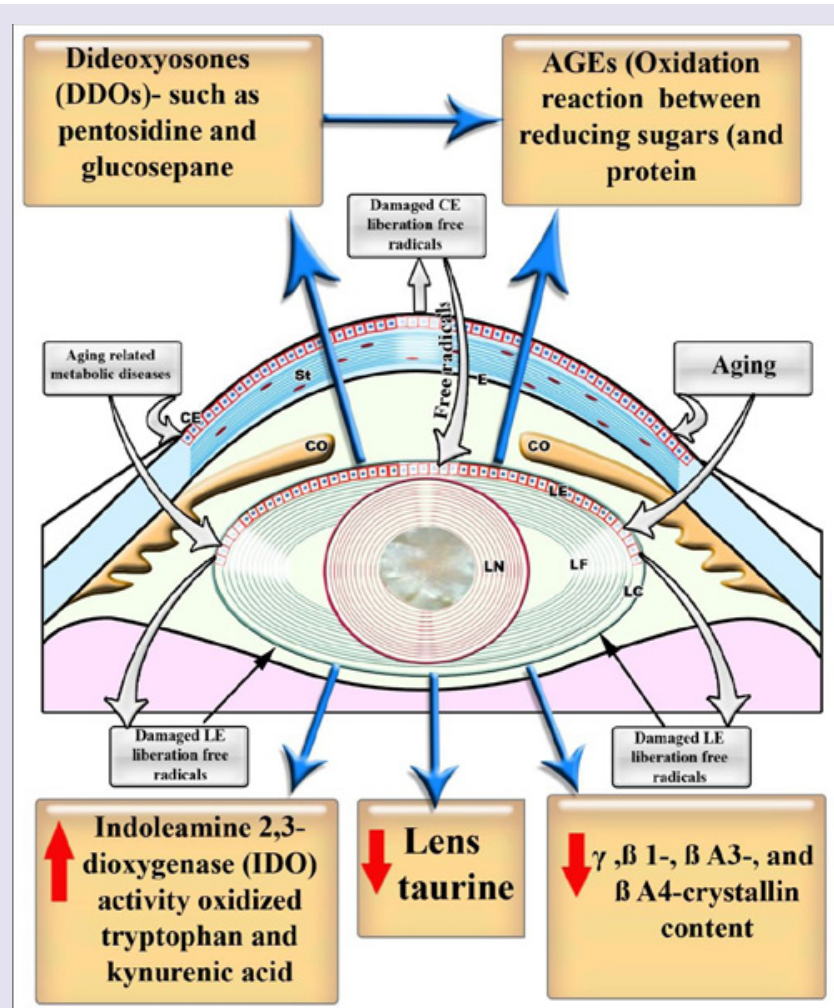

Figure 4: Diagrammatic representation the role of protein in senile cataract formation.

Abbreviations: CE: Corneal Epithelium; CO: Ciliary Organ; E: Endothelium; LC: Lens Capsule; LE: Lens Epithelium; LF: Lens Fiber; LN: Lens Nucleus; St: Stroma. 
markedly detected in cataract formation (Figure 4) [95].

Opacification of the ICR/f mutant lenses was found to be accompanied by changes in crystallin structure and composition, including several deletions of the $\mathrm{N}$-terminals of beta-crystallins and low molecular weight alpha-crystallins [96].

Cataractous lens proteins exhibited apparent decrease in gamma-, betaB1-, betaA3-, and betaA4-crystallin content, accompanied with some increase in alpha-crystallin (or its aggregate). Higher molecular weight proteins were also observed in the form of cross-linked dimers (43 to $55 \mathrm{kDa}$ ) of beta-crystallins [97]. Deletions of the N-terminals of beta-crystallins and low molecular weight alpha-crystallins were detected in cataractous ICR/f mutant lenses [96]. Aggregation of chromophores and insoluble crystallin led to the formation of a brown nuclear cataract while cortical type resulted from impairing of membrane permeability and altered enzyme function [88].

Linetsky et al. stated that ascorbic acid, but not glucose, fructose, ribose or erythrulose, facilitated the aggregation and glycation of calf lens crystallins [98]. Dipeptidyl peptidase III was markedly increased in cataractous lens to an apparent 45.5 -fold over that of the original aqueous extract [99]. There are two forms of cataractous lenses, one with a low internal sodium and calcium content which behaves in a manner similar to normal lenses. Elevated level of sodium ion was found to be involved in alterations of amino acid accumulation, however calcium ions seem to play a critical role in the disturbance of lens protein synthesis [100]. Water-insoluble, high molecular weight protein represents the major component of human nuclear cataracts [101].

AGEs formation resulted from oxidation reaction between reducing sugars and protein which caused lens opacification. Diabetes showed more glycation in patients suffering from diabetes compared with non-diabetic. Pyrraline is an advanced Maillard reaction formed by oxidation of glucose with lysine residues on proteins. This reaction involves an intermediate metabolite, 3-deoxyglucosone which is markedly increased in diabetic lenses $[38,102]$.

Lens proteins possessed the higher levels of dideoxyosones (DDOs): intermediates in the synthesis of advanced glycation endproducts (AGEs), such as pentosidine and glucosepane [103] Deamidation of glutamine and asparagine residues was observed in older lenses [104].

One of the possible roles of inducing lenticular diabetic cataract is the capability of glycated proteins producing reactive oxygen species (ROS), which oxidized tryptophan (Trp) into kynurenines [105,106]. There were marked differences in the amounts of oxindolealanine (OIA, tryptophan oxidation product) in the nucleus versus the cortex in human cataractous lenses [107]. Lenticular levels of Indoleamine 2, 3-dioxygenase (IDO) activity, IDO mRNA, IFN-gamma mRNA, oxidize tryptophan (Trp) and kynurenic acid (KYNA) increased significantly in 60 days diabetic rats [106]. Histidinoalanine and lanthionine were the most abundant dehydroalanine crosslinks in both water-soluble and -insoluble lens proteins in cataractous lenses of Indian patients [108].

Another view of cataract formation is believed to have resulted from a decrease in the antioxidant defense of the lens, particularly the vitamin C concentration. Upon oxidation, vitamin C was found to have combined with glucose to form protein glycation. The lens vitamin $\mathrm{C}$ concentration significantly decreased with cataract severity, especially in severe brown cataracts. The peptide tryptophan content was stable but the tryptophan to tyrosine ratio decreased and was highly correlated to the ascorbic acid concentration [109]. Taurine and total protein were detected in cataractous lenses and involved in altering the structural integrity and permeability of lens membrane to protein and amino acids [110]. Taurine showed antioxidant capacity and was markedly depleted in diabetic cataract. The culture of lenses in high glucose medium increased the weight and opacity of the lenses due to increase of carbonylated protein level, and decrease of glutathione (GSH) content [111].

\section{Minerals and Cataract}

\section{Sodium \& potassium}

Electrolyte balance is of vital importance to the lens transparency in mammals including humans. Its permeability depends on different ion channels such as potassium, sodium, chloride, and calcium channels. The ions may move across a number of electrical silent system such as $\mathrm{Na}^{+} / \mathrm{H}^{+}, \mathrm{Na}^{+} / \mathrm{Ca}^{2+} \mathrm{HCO}^{3-} / \mathrm{Cl}$ - exchange mechanisms as well as active transporters such as $\mathrm{Na}-\mathrm{K}$-ATPase $[112,113]$. Na, K-ATPase activity plays an important role in maintaining the functional activity in lens. Two apparent roles of the enzyme activity were observed more in the epithelium than in the lens fibers. During aging, oxidation and glycation of lens fibers may decrease Na, K-ATPase activity which is markedly detected in the nuclear region $[114,115]$. There is a close association between abnormal elevation of lens sodium and the opacification of the human lens cortex [116]. Aging has also led to alteration of $\mathrm{Na} / \mathrm{K}$ permeability toward the center of the lens as well as impairing the functional activity of the Na-K-ATPase to hydrolyze adenosine triphosphate [117]. Increasing extracellular $\mathrm{K}^{+}$was found to depolarize the lens potential, reducing and reversing the magnitude of the net current densities around the lens [118].

There are two forms of cataractous lenses, one with a low internal sodium and calcium content behaving in a similar manner to normal lenses, and the other with high sodium and calcium contents which showed a markedly reduced ability to accumulate amino acid and synthesized low molecular weight protein. Sodium ion was found to be involved in alterations of amino acid accumulation, however calcium ions seems to play a critical role in the disturbance of lens protein synthesis and also protein-protein interaction [119].

\section{Magnesium}

Magnesium represents one of the main elements in regulating the lens function. It maintains the function of more than 350 enzymes by regulating the intracellular ionic environment of the body ATPase. Its deficiency led to impairments of ATPase functions leading to marked increased of intracellular calcium and sodium and decrease intracellular potassium concentration and development of cataract. Consequently, magnesium deficiency has also contributed to the increase of oxidative stress and inducible NOS stimulation that can initiate the progress of cataract, glaucoma and diabetic retinopathy $[120,121]$.

\section{Zinc}


Zinc plays an integral role in maintaining normal ocular function. The zinc content of human lenses was significantly elevated in mature cataracts compared to cortico-nuclear cataracts. The increase of the lens zinc content was markedly increased with the change in lens coloration from light to dark brown colouration. Diabetic patients were found to show both increased zinc and iron contents in the lens. Zinc and iron were markedly increased in cataractous lenses [122].

Lens opacification in diabetic patient was found to possess increased level of $\mathrm{Cu}$ content than $\mathrm{Zn}$ and Fe content [123]. Patients with either pseudoexfoliative or senile cataract showed increased serum level of both iron and copper [124].

a-Crystallin, is a member of the small heat shock protein family present in the mammalian lens. The stability of $\alpha$-crystallin is increased in the presence of $\mathrm{Zn}\left({ }^{2+}\right)$. H79, $\mathrm{H} 107$ and $\mathrm{H} 115$ of aAcrystallin and H104, H111 and H119 of aB-crystallin are identified as the $\mathrm{Zn}\left({ }^{2+}\right)$ binding residues [125]. Development of lens opacities was associated with lack of copper-zinc superoxide dismutase which participated in an antioxidant capacity [126].

There is a close association between mineral and antioxidant defense. Cataractous lens possessed a decrease of $\mathrm{Cu} / \mathrm{Zn}$ - and $\mathrm{Mn}$ SOD activity and $\mathrm{Cu} / \mathrm{Zn}$-SOD transcript. The decrease of superoxide dismutase activity in cataractous lenses was associated with the decreased level of mRNA transcripts and their protein expression [127].

\section{Iron}

Iron $(\mathrm{Fe})$ is an essential trace element for ocular homeostasis It was found to play a great role in regulating L-cystine uptake and consequently promoting the activity of aconitase in production of glutathione in lens epithelium and retinal pigmented epithelium that led to elevation of the antioxidative capacity against oxidative stress [128]. During the development of lens epithelial cells into lens fiber, both ferritin $\mathrm{H}$ and $\mathrm{L}$ chains were altered with increase in the mass of lens fiber [129]. Iron pathway may occurred through different mechanisms; (i) iron is actively transmitted from the retina to the aqueous humor by a ferroportin/ferroxidase-mediated process through Müller cells, (ii) binding of iron with vitreal transferrin and then diffusing towards the lens, (iii) Incorporation of iron/ transferrin complex with lens extracellular space and infiltrated into the epithelial-fiber interface, (iv) iron/transferrin complex is endocytosed by epithelial cells and drained with the aqueous humor into systemic blood circulation for recycling [130].

Transferrin and Fe concentrations were found to be increased in the intraocular fluids during inflammation and pathological conditions. There was a close relationship between the amount of Fe-transferrin and development of cataractous lenses [131]. The ferritin levels in the cataractous lens nuclei appeared to be markedly increased than that of the cortex due to the presence of ferritin within an insoluble protein fraction of the homogenized lenses. Both nuclei and cortices showed heavily redox-active metals staining [132]. Hyperferritinemia cataract formation was found to result from a mutation in the L-ferritin gene (C33T) which interferes with function of the L-ferritin transcript in an RNA gel shift assay [133].

$\mathrm{Cu}$ and $\mathrm{Fe}$ lacking a non protein-binding condition, initiate the liberation of reactive oxygen species, thereby affecting tissue and cell structures [134]. Abnormal metabolism of $\mathrm{Zn}, \mathrm{Cu}$ and Fe may be influenced in diabetic complications [134], especially $\mathrm{Cu}$ which reached a high peak in the blood of diabetic patients [135] compared with low peak of zinc $[136,137]$ and iron [138].

Iron was found to have contributed in ocular diseases, including glaucoma, cataract, AMD, and intraocular hemorrhage [139]. Numerous genes encoding proteins involved in iron transport and homeostasis are promoted by hypoxia inducible factor. Low oxygen level was found to stimulate the lens epithelial cells (LEC) to trap the cytosolic iron and increased the risk of iron inducing the formation of reactive oxygen species (ROS) and oxidative cell damage [140].

Diabetic cataractous lenses of rats were found to possess increased level of $\mathrm{Zn}$ and $\mathrm{Fe}$ and decreased level of K [141]. In senile cataractous lenses, $\mathrm{Fe}, \mathrm{Al}, \mathrm{Zn}$ and Ca levels were markedly increased. The calcium/ phosphorous ratio was 50 times (1:0.02) greater than in clear lenses [142]. Senile cataractous lenses were found to possess elevated level of nickel and iron with concomitant depletion of chromium, manganese and aluminum, the promoter of cataract formation [143]. Li et al. detected degenerated lens fibers in nuclear cataract associated with aggregation of gamma-crystallin in lens fibers lacking actin filaments and increased calcium concentration of homozygous mutant mouse [144].

\section{Calcium}

Calcium plays a great role in large numbers of cellular regulatory pathways. The transmembrane influx of $\left.\mathrm{Ca}^{(2+}\right)$ through $\mathrm{Ca}(\mathrm{v})$ channels has contributed to the biological function of human lens epithelium [145].

$\mathrm{Ca}\left({ }^{2+}\right)$-ATPase activity was approximately $50 \%$ less in membranes prepared from cataractous lenses in comparison to clear lenses [146]. Marian et al. reported that the increased calcium concentration in cataractous lens was attributed to the increase of calcium-ATPase expression in its plasma membrane [147]. Activation of Ca-dependent enzymes may cause irreversible breakdown of structural proteins and apparent cell death of lens cells [148].

Excessive levels of $\mathrm{Ca}^{2+}$ in human lenses with cortical cataract have been found to play a major role in the opacification process. Ca2 attained 10,000 fold increase in human aqueous humour inwardly directed gradient across the plasma membrane and these are needed to maintain reduction. Both $\mathrm{Na} / \mathrm{Ca} 2$ exchanger (NCX) and plasma membrane Ca2-ATPase (PMCA) actively remove Ca2 from the cells, whereas in endoplasmic reticulum, the Ca2-ATPase (SERCA) facilitated the storage of $\mathrm{Ca}^{++}$. Adenosine triphosphatase was found to be more active in lens epithelial cells compared with that of NCX in fiber cells. Activation of these channels may lead to a rapid increase in pathological calcium overload which facilitates the formation of cataract [149]. Plasma membrane calcium ATPase (PMCA) mRNA and protein levels attained a considerable higher level in cataractous lens which might be a compensatory mechanism to overcome increased intracellular calcium levels [147]. Chen et al. observed ATPbinding cassette protein (ABCA3) in human lens capsule, choroidretinal pigment epithelium and retinal pigment epithelial cells [150]. Mutation of ABCA3 protein was found to be associated with cataractmicrocornea syndrome.

Lenticular copper, lead, cadmium and calcium levels were 
markedly increased in cataractous human lenses especially in males. Cataract formation in diabetic patients possessed a higher concentration of copper which coincides with copper-containing superoxide dismutase and liberation of free radicals. Increased copper ions were attributed to its release from copper-containing enzymes affected by oxidative stress of hyperglycaemia and free radicals [151].

Maintenance of calcium homeostasis is important for the clarity of the lens. $\mathrm{Ca}\left({ }^{2+}\right)$-ATPase play a great role for the removal of cytosolic calcium, either across the plasma membrane or through intracellular organelles such as the endoplasmic reticulum. The activity of $\mathrm{Ca}\left({ }^{2+}\right)-$ ATPase reached approximately $50 \%$ in membranes prepared from nuclear subcapsular, nuclear and brunescent cataracts [146].

The lenticular $\mathrm{Ca}^{2+}$ was found to be maintained by either plasma membrane $\mathrm{Ca}^{2+}$ pumps [152], or plasma membrane $\mathrm{Na}^{+}: \mathrm{Ca}^{2+}$ exchangers [153], and endoplasmic reticulum $\mathrm{Ca}^{2+}$ pumps [152] Cataractous lenses as a result of increased calcium concentration were observed in 14 out of 406 affected human lenses [154]. Odeigah and Patmore detected epithelial hyperplasia in cataractous lens of HY-1 genotype chick lenses and attributed it to the increased calcium binding capacity and elevated sialic acid [155]. Kuck and Kuck mentioned that mouse cataract was different from human senile cataracts due to invariable accumulation of calcium depending on the severity of cataract formation [156].

Cataractous lenses possessed abnormal intracellular ionic environment associated with increased levels of calcium $\left(\mathrm{Ca}^{2+}\right)$, sodium $\left(\mathrm{Na}^{+}\right)$, magnesium $\left(\mathrm{Mg}^{2+}\right)$ and potassium $\left(\mathrm{K}^{+}\right), \mathrm{Mg}^{2+}$ deficiency was found to enhances nitrous oxide production via inducible nitric oxide synthase in the lens and accelerate the progression of lens opacification $[157,158]$. Increased calcium ions in cataract [159], may activate calpain and transglutaminase, the markers of cataracts [160].

Lenticular cataracts were found to exhibit abnormal intracellular ions including increased level of calcium and sodium and depletion of magnesium and potassium. These were associated with a decrease of ATP and adenosine triphosphatase activity as well as increase of nitrous oxide production [158].

Depletion of $\mathrm{Cu}, \mathrm{Zn}$-SOD and catalase (CAT) activities associated with increase of malodialdhyde were detected in diabetic and senile cataractous patients [161].

Increase zinc, copper, and calcium; and a decrease in potassium concentration have a great role in cataractous lenses [162]. Copper ions attained a higher concentration in cataractous lenses of diabetic patients due to decrease in the reactivity of the copper-containing enzyme superoxide dismutase and an increase in hydrogen peroxide concentration [151].

\section{Antioxidant defense}

Ocular tissues contain antioxidants that protect it from oxidative stress of free radicals such as redox antioxidant enzymes (catalase, superoxide dismutase, GSH peroxidase, glutathione S-transferase), ascorbic acid, glutathione, amino acids (cysteine and tyrosine) etc., $[163,164]$ that scavenge free radicals. The antioxidant redox system was detected in the epithelial layer and outer cortical regions.

Fecondo and Augusteyn reported a marked depletion of superoxide dismutase and glutathione peroxidase in the nuclear cataract of human, calf, rabbit and rat lenses [165]. Cataract formation is believed to be attributed to oxidative stress and reduction of the antioxidant defense, especially vitamin $\mathrm{C}$ concentration. Vitamin $\mathrm{C}$ was found to initiate glucose to protein glycation. Lens vitamin $\mathrm{C}$ concentration attained marked depletion in severe brown cataracts ( $88 \mathrm{mumol} / 100 \mathrm{~g}$ lens in mild cataracts, and $50 \mathrm{mumol} / 100 \mathrm{~g}$ in dark brown lenses) [109].

There was a detected reduction of the blood antioxidant redox chain and increase of thiobarbituric acid was found to be indicator of cataractous lenses in diabetic [166] and senile cataractous patients [167-169]. Jain and Bulakh confirmed similar findings of depletion in glutathione peroxidase and increase of thiobarbituric acid in cataractous lenses [170].

Lipid peroxidation (LPO) represent the main cause of cataract formation, initiated by enhanced production of oxygen free radicals in the eye fluids and tissues and inhibited antioxidant enzymatic and non-enzymatic defenses of the lens. The LPO products (diene conjugates, lipid hydroperoxides) and end products of fluorescent LPO were markedly detected in the aqueous humor samples of cataractous patients [171]. Lipid peroxidation led to degradation of the double bonds of unsaturated membrane hydrocarbon and altered the carbonyl and phosphate-oxygen sites of the fiber cell membranes [172]. These oxidative damages initiated in the absence of antioxidant defense [173].

The formation of cataract is believed to have resulted from an oxidative insult which decreases the antioxidant defense of the lens, especially vitamin $\mathrm{C}$. The lens vitamin $\mathrm{C}$ concentration significantly decreased with cataract severity, but mostly in severe brown cataracts [109].

The authors finally concluded that both congenital and senile cataractous lenses resulted from multifactorial agents included genetic, biochemical transformations and alterations in antioxidant defences

\section{References}

1. Beby F, Morle L, Michon L, M B, Edery P, et al. (2003) The genetics of hereditary cataract. J Fr Ophtalmol 26: 400-408.

2. Bhat SP (2001) The ocular lens epithelium. Biosci Rep 21: 537-563

3. Kardong KV (2008) Vertebrates: Comparative anatomy, function, evolution (5th ed.). Boston: McGraw-Hill, pp. 676-677.

4. Mathias RT, White TW, Gong X (2010) Lens gap junctions in growth, differentiation, and homeostasis. Physiol Rev 90: 179-206.

5. Minassian DC, Reidy A, Desai P, Farrow S, Vafidis G, et al. (2000) The deficit in cataract surgery in England and Wales and the escalating problem of visual impairment: epidemiological modeling of the population dynamics of cataract. $\mathrm{Br} J$ Ophthalmol 84: 4-8.

6. Graw J (2003) The genetic and molecular basis of congenital eye defects. Nat Rev Genet 4: 877-888.

7. Hammond CJ, Duncan DD, Snieder H, de Lange M, West SK, et al. (2001) The heritability of age-related cortical cataract: the twin eye study. Invest Ophthalmol Vis Sci 42: 601-605

8. Robman L, Taylor H (2005) External factors in the development of cataract. Eye (Lond) 19: 1074-1082.

9. Kohn BA (1976) The differential diagnosis of cataracts in infancy and childhood. Am J Dis Child 130: 184-192. 
Citation: El-Sayyad HIH, Bakr EHM, El-Ghawet HA, El-Desoky TMGE. Overview of Congenital, Senile and Metabolic Cataract . J Ocular Biol. 2015;3(2): 12

ISSN: 2334-2838

10. Lambert SR, Amaya L, Taylor D (1989) Detection and treatment of infantile cataracts. Int Ophthalmol Clin 29: 51-56

11. Guleria K, Sperling K, Singh D, Varon R, Singh JR, et al. (2007) A novel mutation in the connexin 46 (GJA3) gene associated with autosomal dominan congenital cataract in an Indian family. Mol Vis 13: 1657-1665.

12. Rahi JS, Dezateux C (1999) National cross sectional study of detection of congenital and infantile cataract in the United Kingdom: role of childhood screening and surveillance. The British Congenital Cataract Interest Group. BMJ 318: 362-365

13. Brazitikos PD, Tsinopoulos IT, Papadopoulos NT, Fotiadis K, Stangos NT (1999) Ultrasonographic classification and phacoemulsification of white senile cataracts. Ophthalmology 106: 2178-2183.

14. Lin TJ, Peng CH, Chiou SH, Liu JH, Lin-Chung-Woung, et al. (2011) Severity of lens opacity, age, and correlation of the level of silent information regulator $\mathrm{T} 1$ expression in age-related cataract. J Cataract Refract Surg 37: 12701274

15. Reddy PY, Giridharan NV, Reddy GB (2012) Activation of sorbitol pathway in metabolic syndrome and increased susceptibility to cataract in Wistar-Obese rats. Mol Vis 18: 495-503.

16. Nagai $N$, Ito $Y$ (2014) Excessive hydrogen peroxide enhances the attachmen of amyloid $\beta 1-42$ in the lens epithelium of UPL rats, a hereditary model for cataracts. Toxicology 315: 55-64.

17. Javadi MA, Zarei-Ghanavati S (2008) Cataracts in diabetic patients. Ophthalmic Vis Res 3: 52-65

18. Ornek K, Karel F, Büyükbingöl Z (2003) May nitric oxide molecule have a role in the pathogenesis of human cataract? Exp Eye Res 76: 23-27.

19. Yu X, Lyu D, Dong X, He J, Yao K (2014) Hypertension and risk of cataract: a meta-analysis. PLoS One 9: e114012.

20. Moncaster JA, Pineda R, Moir RD, Lu S, Burton MA, et al. (2010) Alzheimer's disease amyloid-beta links lens and brain pathology in Down syndrome. PLoS One 5: e10659.

21. Tkachov SI, Lautenschlager C, Ehrich D, Struck HG (2006) Changes in the lens epithelium with respect to cataractogenesis: light microscopic and Scheimpflug densitometric analysis of the cataractous and the clear lens of diabetics and non- diabetics. Graefes Arch Clin Exp Ophthalmol 244: 596602.

22. Hashim Z, Zarina S (2012) Osmotic stress induced oxidative damage: possible mechanism of cataract formation in diabetes. J Diabetes Complications 26 $275-279$.

23. Gupta SK, Selvan VK, Agrarwal SS, Saxena R (2009) Advances in pharmacological strategies for the prevention of cataract development. Indian J Ophthalmol 57: 175-183.

24. Jung HA, Islam MD, Kwon YS, Jin SE, Son YK, et al. (2011) Extraction and identification of three major aldose reductase inhibitors from Artemisia Montana. Food Chem Toxicol 49: 376-384.

25. Beyer-Mears A, Cruz E (1985) Reversal of diabetic cataract by sorbinil, an aldose reductase inhibitor. Diabetes 34: 15-21.

26. Kador PF, Lee JW, Fujisawa S, Blessing K, Lou MF (2000) Relative importance of aldose reductase versus nonenzymatic glycosylation on sugar cataract formation in diabetic rats. J Ocul Pharmacol Ther 16: 149-160.

27. Akagi Y, Kador PF, Kinoshita JH (1987) Immunohistochemical localization for aldose reductase in diabetic lenses. Invest Ophthalmol Vis Sci 28: 163-167.

28. Lightman S (1993) Does aldose reductase have a role in the development of the ocular complications of diabetes? Eye (Lond) 7: 238-241.

29. Takamura Y, Sugimoto Y, Kubo E, Takahashi Y, Akagi Y (2001) Immunohistochemical study of apoptosis of lens epithelial cells in human and diabetic rat cataracts. Jpn J Ophthalmol 45: 559-563.

30. Drel VR, Xu W, Zhang J, Kador PF, Ali TK, et al. (2009) Poly(ADP-ribose) polymerase inhibition counteracts cataract formation and early retina changes in streptozotocin-diabetic rats. Invest Ophthalmol Vis Sci 50: 1778-
1790.

31. Schreiber V, Dantzer F, Ame JC, de Murcia G (2006) Poly(ADP-ribose): novel functions for an old molecule. Nat Rev Mol Cell Biol 7: 517-528.

32. Mulhern ML, Madson CJ, Danford A, Ikesugi K, Kador PF, et al. (2006) The unfolded protein response in lens epithelial cells from galactosemic rat lenses. Invest Ophthalmol Vis Sci 47: 3951-3959.

33. Thiagarajan R, Manikandan R (2013) Antioxidants and cataracts. Free Radic Res 47: 337-345

34. Snow A, Shieh B, Chang KC, Pal A, Lenhart P, et al. (2015) Aldose reductase expression as a risk factor for cataract. Chem Biol Interact 234: 247-253.

35. Kinoshita JH (1974) Mechanisms initiating cataract formation. Invest Ophthalmol 13: 713-724.

36. Nagai N, Ito Y, Takeuchi N, Usui S, Hirano K (2008) Comparison of the mechanisms of cataract development involving differences in $\mathrm{Ca} 2+$ regulation in lenses among three hereditary cataract model rats. Biol Pharm Bull 31: 1990-1995.

37. Monnier VM, Stevens VJ, Cerami A (1979) Nonenzymatic glycosylation, sulfhydryl oxidation and aggregation of lens proteins in experimental sugar cataracts. J Exp Med 150: 1098-1107.

38. Hashim Z, Zarina S (2011) Advanced glycation end products in diabetic and non-diabetic human subjects suffering from cataract. Age (Dordr) 33: 377 384.

39. Kim J, Kim OS, Kim CS, Sohn E, Jo K, et al. (2012) Accumulation of argpyrimidine, a methylglyoxal-derived advanced glycation end product, increases apoptosis of lens epithelial cells both in vitro and in vivo. Exp Mo Med 44: 167-175.

40. Peppa M, Uribarri J, Vlassara H (2004) The role of advanced glycation end products in the development of atherosclerosis. Curr Diabetes Rep 4: 31-36.

41. Bras ID, Colitz CM, Kusewitt DF, Chandler H, Lu P, et al. (2007) Evaluation of advanced glycation end-products in diabetic and inherited canine cataracts. Graefes Arch Clin Exp Ophthalmol 245: 249-257.

42. Gul A, Rahman MA, Salim A, Simjee SU (2009) Advanced glycation end products in senile diabetic and nondiabetic patients with cataract. J Diabetes Complications 23: 343-348

43. Zarina S, Zhao HR, Abraham EC (2000) Advanced glycation end products in human senile and diabetic cataractous lenses. Mol Cell Biochem 210: 29-34.

44. Franke S, Dawczynski J, Strobel J, Niwa T, Stahl P, et al. (2003) Increased levels of advanced glycation end products in human cataractous lenses. $J$ Cataract Refract Surg 29: 998-1004.

45. Raman R, Pal SS, Adams JS, Rani PK, Vaitheeswaran K, et al. (2010) Prevalence and risk factors for cataract in diabetes. Sankara Nethralaya Diabetic Retinopathy Epidemiology And Molecular Genetics Study, report no. 17. Invest Ophthalmol Vis Sci 51: 6253-6261.

46. Kim J, Kim CS, Sohn E, Kim H, Jeong IH, et al. (2010) Lens epithelial cell apoptosis initiates diabetic cataractogenesis in the Zucker diabetic fatty rat. Graefes Arch Clin Exp Ophthalmol 248: 811-818.

47. Semina EV, Ferrell RE, Mintz-Hittner HA, Bitoun P, Alward WL, et al. (1998) A novel homeobox gene PITX3 is mutated in families with autosomal-dominant cataracts and ASMD. Nat Genet 19: 167-170.

48. Merin S, Crawford JS (1971) The etiology of congenital cataracts: a survey of 386 cases. Can J Ophthalmol 6: 178-182.

49. Zhu Y, Yu H, Wang W, Gong X, Yao K (2014) A Novel GJA8 mutation (p.V44A) causing autosomal dominant congenital cataract. PLoS One 9: e115406.

50. Fort PE, Darche M, Sahel JA, Rendon A, Tadayoni R (2014) Lack of dystrophin protein $\mathrm{Dp} 71$ results in progressive cataract formation due to loss of fiber cell organization. Mol Vis 20: 1480-1490.

51. Khan AO, Bergmann C, Neuhaus C, Bolz HJ (2015) A distinct vitreo-retinal dystrophy with early-onset cataract from recessive $\mathrm{KCNJ} 13$ mutations. 
Citation: El-Sayyad HIH, Bakr EHM, El-Ghawet HA, El-Desoky TMGE. Overview of Congenital, Senile and Metabolic Cataract . J Ocular Biol. 2015;3(2): 12

ISSN: 2334-2838

Ophthalmic Genet 36: 79-84.

52. Kondo T, Nagai H, Kawashima T, Taniguchi Y, Koyabu N, et al. (2014) Hereditary and histologic characteristics of the CF1/b cac mouse cataract model. Comp Med 64: 360-368.

53. Chograni M, Alkuraya FS, Ourteni I, Maazoul F, Lariani I, et al. (2015) Autosomal recessive congenital cataract, intellectual disability phenotype linked to STX3 in a consanguineous. Tunisian family. Clin Genet 88: 283-287.

54. Bennett TM, Mackay DS, Siegfried CJ, Shiels A (2014) Mutation of the melastatin-related cation channel, TRPM3, underlies inherited cataract and glaucoma. PLoS One 9: e104000.

55. Congdon NG, Friedman DS, Lietman T (2003) Important causes of visual impairment in the world today. JAMA 290: 2057-2060.

56. Colitz CM, Davidson MG, McGahan MC (1999) Telomerase activity in lens epithelial cells of normal and cataractous lenses. Exp Eye Res 69: 641-649.

57. Babizhayev MA, Vishnyakova KS, Yegorov YE (2011) Telomere-dependen senescent phenotype of lens epithelial cells as a biological marker of aging and cataractogenesis: the role of oxidative stress intensity and specific mechanism of phospholipid hydroperoxide toxicity in lens and aqueous. Fundam Clin Pharmacol 25: 139-162.

58. Worgul BV, David J, Odrich S, Merriam GR Jr, Medvedovsky C, et al. (1991) Evidence of genotoxic damage in human cataractous lenses. Mutagenesis 6: 495-499.

59. Qin Y, Zhao J, Min X, Wang M, Luo W, et al. (2014) MicroRNA-125b inhibits lens epithelial cell apoptosis by targeting p53 in age-related cataract. Biochim Biophys Acta 1842: 2439-2447.

60. Wang Y, Li F, Zhang G, Kang L, Qin B, et al. (2015) Altered DNA methylation and expression profiles of 8-oxoguanine DNA glycosylase 1 in lens tissue from age-related cataract patients. Curr Eye Res 40: 815-821.

61. Sireesha R, Laxmi SG, Mamata M, Reddy PY, Yadagiri, Goud PU, et al. (2012) Total activity of glutathione-S-transferase (GST) and polymorphisms of GSTM1 and GSTT1 genes conferring risk for the development of age related cataracts. Exp Eye Res 98: 67-74.

62. Hasanova N, Kubo E, Kumamoto Y, Takamura Y, Akagi Y (2009) Age-related cataracts and Prdx6: correlation between severity of lens opacity, age and the level of Prdx 6 expression. Br J Ophthalmol 93: 1081-1084.

63. Palsamy P, Ayaki M, Elanchezhian R, Shinohara T (2012) Promoter demethylation of Keap1 gene in human diabetic cataractous lenses. Biochem Biophys Res Commun 423: 542-548.

64. Palsamy P, Bidasee KR, Ayaki M, Augusteyn RC, Chan JY, et al. (2014) Methylglyoxal induces endoplasmic reticulum stress and DNA demethylation in the Keap1 promoter of human lens epithelial cells and age-related cataracts. Free Radic Biol Med 72: 134-148.

65. Gao Y, Yan Y, Huang T (2015) Human age related cataracts: epigenetic suppression of the nuclear factor erythroid 2 related factor 2 mediated antioxidant system. Mol Med Rep 11: 1442-1447.

66. Firtina Z, Danysh BP, Bai X, Gould DB, Kobayashi T, et al. (2009) Abnormal expression of collagen IV in lens activates unfolded protein response resulting in cataract. J Biol Chem 284: 35872-35884.

67. Terrell AM, Anand D, Smith SF, Dang CA, Waters SM, et al. (2015) Molecular characterization of mouse lens epithelial cell lines and their suitability to study RNA granules and cataract associated genes. Exp Eye Res 131: 42-55.

68. Pól J, Vidová V, Hyötyläinen T, Volný M, Novák P, et al. (2011) Spatial distribution of glycerophospholipids in the ocular lens. PLoS One 6: e19441.

69. Borchman D, Yappert MC (2010) Lipids and the ocular lens. J Lipid Res 51 2473-2488.

70. Ogiso M (1998) Implication of glycolipids in lens fiber development. Acta Biochim Pol 45: 501-507.

71. Mohanty BP, Bhattacharjee S, Paria P, Mahanty A, Sharma AP (2013) Lipid biomarkers of lens aging. Appl Biochem Biotechnol 169: 192-200.
72. Raguz M, Mainali L, O'Brien WJ, Subczynski WK (2014) Lipid-protein interactions in plasma membranes of fiber cells isolated from the human eye lens. Exp Eye Res 120: 138-151.

73. Babizhayev MA (2005) Analysis of lipid peroxidation and electron microscopic survey of maturation stages during human cataractogenesis: pharmacokinetic assay of Can-C N-acetylcarnosine prodrug lubricant eye drops for cataract prevention. Drugs R D 6: 345-369.

74. Ariga T, Tao RV, Lee BC, Yamawaki M, Yoshino H, et al. (1994) Glycolipid composition of human cataractous lenses. Characterization of Lewisx glycolipids. J Biol Chem 269: 2667-2675.

75. Siddique MA, Tiwary BK, Paul SB (2010) Phospholipid and protein contents of lens proteolipids in human senile cataract. Eye (Lond) 24: 720-727.

76. Simonelli F, Libondi T, Romano N, Nunziata G, D'Aloia A et al. (1996) Fatty acid composition of membrane phospholipids of cataractous human lenses. Ophthalmic Res 28 Suppl 1: 101-104.

77. Huang L, Grami V, Marrero Y, Tang D, Yappert MC, et al. (2005) Human lens phospholipid changes with age and cataract. Invest Ophthalmol Vis Sci 46: 1682-1689.

78. Fleschner CR, Cenedella RJ (1991) Lipid composition of lens plasma membrane fractions enriched in fiber junctions. J Lipid Res 32: 45-53.

79. Girão H, Mota MC, Ramalho J, Pereira P (1998) Cholesterol oxides accumulate in human cataracts. Exp Eye Res 66: 645-652.

80. Widomska J, Raguz M, Subczynski WK (2007) Oxygen permeability of the lipid bilayer membrane made of calf lens lipids. Biochim Biophys Acta 1768: 2635-2645.

81. Bassnett S (2002) Lens organelle degradation. Exp Eye Res 74: 1-6.

82. McNulty R, Wang H, Mathias RT, Ortwerth BJ, Truscott RJ, et al. (2004) Regulation of tissue oxygen levels in the mammalian lens. J Physiol 559: 883-898.

83. Deeley JM, Mitchell TW, Wei X, Korth J, Nealon JR, et al. (2008) Human lens lipids differ markedly from those of commonly used experimental animals. Biochim Biophys Acta 1781: 288-298.

84. Ogiso M, Nishiyama I, Saito N, Okinaga T, Hoshi M, et al. (1995) Localization of neutral and acidic glycosphingolipids in rat lens. Glycobiology 5: 187-194.

85. Saito M, Sugiyama K (2000) Gangliosides of rat eye lens: a severe reduction in the content of C-series gangliosides following streptozotocin treatment. Life Sci 67: 1891-1899.

86. Varma SD, Devamanoharan PS, Mansour S, Teter B (1994) Studies on Emory mouse cataracts: oxidative factors. Ophthalmic Res 26: 141-148.

87. Takemoto L, Sorensen CM (2008) Protein-protein interactions and lens transparency. Exp Eye Res 87: 496-501.

88. Michael R, Bron AJ (2011) The ageing lens and cataract: a model of normal and pathological ageing. Phil Trans R Soc Lond B Biol Sci 366: 1278-1292.

89. Garner MH, Spector A (1980) Selective oxidation of cysteine and methionine in normal and senile cataractous lenses. Proc Natl Acad Sci U S A 77: $1274-$ 1277.

90. Xia CH, Liu H, Chang B, Cheng C, Cheung D, et al. (2006) Arginine 54 and Tyrosine 118 residues of \{alpha\}A-crystallin are crucial for lens formation and transparency. Invest Ophthalmol Vis Sci 47: 3004-3010.

91. Takemoto LJ (1996) Oxidation of cysteine residues from alpha-A crystallin during cataractogenesis of the human lens. Biochem Biophys Res Commun 223: $216-220$.

92. Lampi KJ, Wilmarth PA, Murray MR, David LL (2014) Lens $\beta$-crystallins: the role of deamidation and related modifications in aging and cataract. Prog Biophys Mol Biol 115: 21-31.

93. Dickerson JE Jr, Lou MF (1993) A new mixed disulfide species in human cataractous and aged lenses. Biochim Biophys Acta 1157: 141-146.

94. Ho MC, Peng YJ, Chen SH, Chiou SH (2010) Senile cataracts and oxidative stress. J Clin Gerontol Geriatr 1: 17-21. 
Citation: El-Sayyad HIH, Bakr EHM, El-Ghawet HA, El-Desoky TMGE. Overview of Congenital, Senile and Metabolic Cataract . J Ocular Biol. 2015;3(2): 12

ISSN: $2334-2838$

95. Molnár GA, Nemes V, Biró Z, Ludány A, Wagner Z, et al. (2005) Accumulation of the hydroxyl free radical markers meta-, ortho-tyrosine and DOPA in cataractous lenses is accompanied by a lower protein and phenylalanine content of the water-soluble phase. Free Radic Res 39: 1359-1366.

96. Takeuchi N, Ito H, Namiki K, Kamei A (2001) Effect of calpain on hereditary cataractous rat, ICR/f. Biol Pharm Bull 24: 1246-1251.

97. Takeuchi N, Kamei A (2000) Crystallin proteins in lenses of hereditary cataractous rat, ICR/f. Biol Pharm Bull 23: 283-290

98. Linetsky M, Shipova E, Cheng R, Ortwerth BJ (2008) Glycation by ascorbic acid oxidation products leads to the aggregation of lens proteins. Biochim Biophys Acta 1782: 22-34.

99. Swanson AA, Davis RM, McDonald JK (1984) Dipeptidyl peptidase III of human cataractous lenses. Partial purification. Curr Eye Res 3: 287-291.

100. Marcantonio J, Duncan G (1987) Amino acid transport and protein synthesis in human normal and cataractous lenses. Curr Eye Res 6: 1299-1308.

101. Lapko VN, Purkiss AG, Smith DL, Smith JB (2002) Deamidation in human gamma S-crystallin from cataractous lenses is influenced by surface exposure. Biochemistry 41: 8638-8648

102. Nagaraj RH, Sady C (1996) The presence of a glucose-derived Maillard reaction product in the human lens. FEBS Lett 382: 234-238.

103. Linetsky M, Kaid Johar SR, Meltretter J, Padmanabha S, Parmar T, et al (2011) Determination of dideoxyosone precursors of AGEs in human lens proteins. Arch Biochem Biophys 514: 16-26.

104. Hains PG, Truscott RJ (2010) Age-dependent deamidation of lifelong proteins in the human lens. Invest Ophthalmol Vis Sci 51: 3107-3114.

105. Korlimbinis A, Hains PG, TruscottRJ, Aquilina JA(2006)3-Hydroxykynurenine oxidizes alpha-crystallin: potential role in cataractogenesis. Biochemistry 45 1852-1860.

106. Kanth VR, Lavanya K, Srinivas J, Raju TN (2009) Elevated Expression of indoleamine 2,3-dioxygenase (IDO) and accumulation of kynurenic acid in the pathogenesis of STZ-induced diabetic cataract in Wistar rats. Curr Eye Res 34: 274-281.

107. Rousseva LA, Gaillard ER, Paik DC, Merriam JC, Ryzhov V, et al. (2007) Oxindolealanine in age-related human cataracts. Exp Eye Res 85: 861-868

108. Linetsky M, Hill JM, LeGrand RD, Hu F (2004) Dehydroalanine crosslinks in human lens. Exp Eye Res 79: 499-512.

109. Tessier F, Moreaux V, Birlouez-Aragon I, Junes P, Mondon H (1996) Decrease in vitamin $C$ concentration in human lenses during cataract progression. Int J Vitam Nutr Res 68: 309-315.

110. Anthrayose CV, Shashidhar S (2004) Studies on protein and taurine in normal, senile and diabetic cataractous human lenses. Indian J Physiol Pharmacol 48: 357-360.

111. Son HY, Kim H, H Kwon Y (2007) Taurine prevents oxidative damage of high glucose-induced cataractogenesis in isolated rat lenses. J Nutr Sc Vitaminol (Tokyo) 53: 324-330.

112. Duncan G, Webb SF, Dawson AP, Bootman MD, Elliott AJ (1993) Calcium regulation in tissue-cultured human and bovine lens epithelial cells. Invest Ophthalmol Vis Sci 34: 2835-2842.

113. Stewart S, Duncan G, Marcantonio JM, Prescott AR (1988) Membrane and communication properties of tissue cultured human lens epithelial cells. Invest Ophthalmol Vis Sci 29: 1713-1725.

114. Kobatashi S, Roy D, Spector A (1982-1983) Sodium/potassium ATPase in normal and cataractous human lenses. Curr Eye Res 2: 327-334

115. Tamiya S, Dean WL, Paterson CA, Delamere NA (2003) Regional distribution of $\mathrm{Na}, \mathrm{K}-\mathrm{ATPase}$ activity in Porcine lens epithelium. Invest Ophthalmol Vis Sci 44: 4395-4399.

116. Delamere NA, Tamiya S (2004) Expression, regulation and function of $\mathrm{Na}$ K-ATPase in the lens. Prog Retin Eye Res 23: 593-615.

117. Delamere NA, Dean WL (1993) Distribution of lens sodium-potassium- adenosine triphosphatase. Invest Ophthalmol Vis Sci 34: 2159-2163.

118. Vaghefi E, Liu N, Donaldson PJ (2013) A computer model of lens structure and function predicts experimental changes to steady state properties and circulating currents. Biomed Eng Online 12: 85.

119. Marcantonio J, Duncan G (1987) Amino acid transport and protein synthesis in human normal and cataractous lenses. Curr Eye Res 6: 1299-1308.

120. Agarwal R, lezhitsa I, Agarwal P, Spasov A (2012) Magnesium deficiency: does it have a role to play in cataractogenesis? Exp Eye Res 101: 82-89.

121. Agarwal R, lezhitsa IN, Agarwal P, Spasov AA (2013) Mechanisms of cataractogenesis in the presence of magnesium deficiency. Magnes Res 26: $2-8$.

122. Dawczynski J, Blum M, Winnefeld K, Strobel J (2002) Increased content of zinc and iron in human cataractous lenses. Biol Trace Elem Res 90: 15-23.

123. Aydin E, Cumurcu T, Ozugurlu F, Ozyurt H, Sahinoglu S, et al. (2005) Levels of iron, zinc, and copper in aqueous humor, lens, and serum in nondiabetic and diabetic patients: their relation to cataract. Biol Trace Elem Res 108: 33-41.

124. Cumurcu T, Mendil D, Etikan I (2006) Levels of zinc, iron, and copper in patients with pseudoexfoliative cataract. Eur J Ophthalmol 16: 548-553.

125. Karmakar S, Das KP (2012) Identification of histidine residues involved in $\mathrm{Zn}(2+)$ binding to $\alpha \mathrm{A}-$ and $\alpha \mathrm{B}-$ crystallin by chemical modification and MALDI TOF mass spectrometry. Protein J 31: 623-640.

126. Olofsson EM, Marklund SL, Behndig A (2012) Enhanced age-related cataract in copper-zinc superoxide dismutase null mice. Clin Experiment Ophthalmol 40: 813-820

127. Rajkumar S, Vasavada AR, Praveen MR, Ananthan R, Reddy GB, et al (2013) Exploration of molecular factors impairing superoxide dismutase isoforms activity in human senile cataractous lenses. Invest Ophthalmol Vis Sci 54: 6224-6233.

128. Lall MM, Ferrell J, Nagar S, Fleisher LN, McGahan MC (2008) Iron regulates L-cystine uptake and glutathione levels in lens epithelial and retinal pigment epithelial cells by its effect on cytosolic aconitase. Invest Ophthalmol Vis Sci 49: $310-319$

129. Goralska M, Nagar S, Fleisher LN, McGahan MC (2009) Distribution of ferritin chains in canine lenses with and without age-related nuclear cataracts. Mol Vis 15: 2404-2410.

130. García-Castiñeiras S (2010) Iron, the retina and the lens: a focused review. Exp Eye Res 90: 664-678.

131. McGahan MC, Grimes AM, Nasisse MP, Fleisher LN (1995) Iron uptake by cultured lens epithelial cells. Graefes Arch Clin Exp Ophthalmol 233: 354 359.

132. Garner B, Roberg K, Qian M, Eaton JW, Truscott RJ (2000) Distribution of ferritin and redox-active transition metals in normal and cataractous human lenses. Exp Eye Res 71: 599-607.

133. Brooks DG, Manova-Todorova K, Farmer J, Lobmayr L, Wilson RB, et al. (2002) Ferritin crystal cataracts in hereditary hyperferritinemia cataract syndrome. Invest Ophthalmol Vis Sci 43: 1121-1126.

134. Itokawa $Y(1992)$ Diabetes Mellitus and trace elements. Diabetes Frontier 3: $425-433$.

135. Zheng Y, Li XK, Wang Y, Cai L (2008) The role of zinc, copper and iron in the pathogenesis of diabetes and diabetic complications: therapeutic effects by chelators. Hemoglobin 32: 135-145.

136. Ferdousi S, Mia AR, Mahzabeen L, Nath RK, Mollah FH (2013) Serum zinc and magnesium level in newly diagnosed type-2 diabetic subjects. Mymensingh Med J 22: 552-556

137. Al-Timimi DJ, Sulieman DM, Hussen KR (2014) Zinc status in type 2 diabetic patients: relation to the progression of diabetic nephropathy. $\mathrm{J}$ Clin Diagn Res 8: CC04-CC08.

138. Yerlikaya FH, Toker A, Arıbas A (2013) Serum trace elements in obese women with or without diabetes. Indian J Med Res 137: 339-345. 
Citation: El-Sayyad HIH, Bakr EHM, El-Ghawet HA, El-Desoky TMGE. Overview of Congenital, Senile and Metabolic Cataract . J Ocular Biol. 2015;3(2): 12.

ISSN: 2334-2838

139. He X, Hahn P, lacovelli J, Wong R, King C, et al. (2007) Iron homeostasis and toxicity in retinal degeneration. Prog Retin Eye Res 26: 649-673.

140. Goralska M, Fleisher LN, McGahan MC (2014) Hypoxia induced changes in expression of proteins involved in iron uptake and storage in cultured lens epithelial cells. Exp Eye Res 125: 135-141.

141. Liu X, Zhang Y, Zhang S, Zhao Q, Zhang Y, et al. (1990) Study on change in zinc concentration for diabetic cataractous lenses in rats by means of XIXA Hua Xi Yi Ke Da Xue Xue Bao 21: 134-136.

142. Chen CZ (1992) Analysis of 7 elements in the serum and lens of senile cataract patients. Zhonghua Yan Ke Za Zhi 28: 355-357.

143. Cekiç O, Bardak Y, Totan Y, Kavakli S, Akyol O, et al. (1999) Nickel, chromium, manganese, iron and aluminum levels in human cataractous and normal lenses. Ophthalmic Res 31: 332-336.

144. Li L, Chang B, Cheng C, Chang D, Hawes NL, et al. (2008) Dense nuclea cataract caused by the gammaB-crystallin S11R point mutation. Invest Ophthalmol Vis Sci 49: 304-309.

145. Meissner A, Noack T (2008) Proliferation of human lens epithelial cells (HLE-B3) is inhibited by blocking of voltage-gated calcium channels. Pflugers Arch 457: 47-59.

146. Paterson CA, Zeng J, Husseini Z, Borchman D, Delamere NA, et al. (1997) Calcium ATPase activity and membrane structure in clear and cataractous human lenses. Curr Eye Res 16: 333-338.

147. Marian MJ, Mukhopadhyay P, Borchman D, Paterson CA (2008) Plasma membrane Ca-ATPase isoform expression in human cataractous lenses compared to age-matched clear lenses. Ophthalmic Res 40: 86-93.

148. Gupta PD, Johar K, Vasavada A (2004) Causative and preventive action of calcium in cataracto-genesis. Acta Pharmacol Sin 25: 1250-1256.

149. Rhodes JD, Sanderson J (2009) The mechanisms of calcium homeostasis and signalling in the lens. Exp Eye Res 88: 226-234

150. Chen P, Dai $Y$, Wu X, Wang $Y$, Sun $S$, et al. (2014) Mutations in the ABCA3 gene are associated with cataract-microcornea syndrome. Invest Ophthalmol Vis Sci 55: 8031-8043.

151. Lin J (1997) Pathophysiology of cataracts: copper ion and peroxidation in diabetics. Jpn J Ophthalmol 41: 130-137.

152. Duncan G, Jacob TJ (1984) Calcium and the physiology of cataract. Ciba Found Symp 106: 132-152.

153. Galvan A, Louis CF (1988) Calcium regulation by plasma membrane vesicles. Arch Biochem. Biophys 264: 472-481.

154. Harding CV, Chylack LT Jr, Susan SR, Lo WK, Bobrowski WF (1983) Calcium-containing opacities in the human lens. Invest Ophthalmol Vis Sci 24: 1194-1202.

155. Odeigah PG, Patmore L (1985) Increased calcium binding capacity associated with genotypic lens opacities. Ophthalmic Res 17: 338-340.

156. Kuck JF, Kuck KD (1989) The Emory mouse cataract: increased accumulation of calcium during cataractogenesis. Lens Eye Toxic Res 6 :
853-862.

157. Dilsiz N, Olcucu A, Atas M (2000) Determination of calcium, sodium, potassium and magnesium concentrations in human senile cataractous lenses. Cell Biochem Funct 18: 259-262.

158. Nagai N, Fukuhata T, Ito $Y$ (2007) Effect of magnesium deficiency on intracellular ATP levels in human lens epithelial cells. Biol Pharm Bull 30: 6-10.

159. Cekic O (1998) Copper, lead, cadmium and calcium in cataractous lenses. Ophthalmic Res 30: 49-53.

160. Sanderson J, Marcantonio JM, Duncan G (2000) A human lens model of cortical cataract: $\mathrm{Ca} 2+-$ induced protein loss, vimentin cleavage and opacification. Invest Ophthalmol Vis Sci 41: 2255-2261.

161. Hashim Z, Zarina S (2006) Antioxidant markers in human senile and diabetic cataractous lenses. J Coll Physicians Surg Pak 16: 637-640.

162. Rasi V, Costantini S, Moramarco A, Giordano R, Giustolisi R, et al. (1992) Inorganic element concentrations in cataractous human lenses. Ann Ophthalmol 24: 459-464.

163. Garland D (1990) Role of site-specific, metal-catalyzed oxidation in lens aging and cataract: a hypothesis. Exp Eye Res 50: 677-682.

164. Kisic B, Miric D, Zoric L, Ilic A, Dragojevic I (2012) Antioxidant capacity of lenses with age-related cataract. Oxid Med Cell Longev 2012: 467130.

165. Fecondo JV, Augusteyn RC (1983) Superoxide dismutase, catalase and glutathione peroxidase in the human cataractous lens. Exp Eye Res 36: 1523

166. Donma O, Yorulmaz E, Pekel H, Suyugül N (2002) Blood and lens lipid peroxidation and antioxidant status in normal individuals, senile and diabetic cataractous patients. Curr Eye Res 25: 9-16.

167. Altomare E, Vendemiale G, Grattagliano I, Angelini P, Micelli-Ferrari T, et al. (1995) Human diabetic cataract: role of lipid peroxidation. Diabete Metab 21: $173-179$

168. Ozmen B, Ozmen D, Erkin E, Güner I, Habif S, et al. (2002) Lens superoxide dismutase and catalase activities in diabetic cataract. Clin Biochem 35: 6972

169. Ozmen D, Mutaf I, Ozmen B, Mentes J, Bayindir O (1997) Lens lipid peroxides and glutathione concentrations in diabetic cataract. Ann Clin Biochem 34: 190-192.

170. Jain RM, Bulakh PM (2003) Effect of ketoacids on $\mathrm{H}(2) \mathrm{O}(2)$ induced cataract. Indian J Clin Biochem 18: 91-95.

171. Babizhayev MA, Costa EB (1994) Lipid peroxide and reactive oxygen species generating systems of the crystalline lens. Biochim Biophys Acta 1225: 326-337.

172. Lamba OP, Borchman D, Garner WH (1994) Spectral characterization of lipid peroxidation in rabbit lens membranes induced by hydrogen peroxide in the presence of $\mathrm{Fe} 2+/ \mathrm{Fe} 3+$ cations: a site-specific catalyzed oxidation. Free Radic Biol Med 16: 591-601.

173. Babizhayev MA (1996) Failure to withstand oxidative stress induced by phospholipid hydroperoxides as a possible cause of the lens opacities in systemic diseases and ageing. Biochim Biophys Acta 1315: 87-99. 